University of Wollongong

Research Online

Faculty of Engineering and Information

Faculty of Engineering and Information

Sciences - Papers: Part A

Sciences

2013

Effects of tungsten addition and heat treatment conditions on microstructure and mechanical properties of microalloyed forging steels

Jingwei Zhao

University of Wollongong, jzhao@uow.edu.au

Zhengyi Jiang

University of Wollongong, jiang@uow.edu.au

Chong Soo Lee

Pohang University of Science and Technology, cslee@postech.ac.kr

Follow this and additional works at: https://ro.uow.edu.au/eispapers

Part of the Engineering Commons, and the Science and Technology Studies Commons

Research Online is the open access institutional repository for the University of Wollongong. For further information contact the UOW Library: research-pubs@uow.edu.au 


\title{
Effects of tungsten addition and heat treatment conditions on microstructure and mechanical properties of microalloyed forging steels
}

\author{
Abstract \\ In the present work, the effects of tungsten (W) addition and heat treatment conditions on the \\ microstructure, impact toughness and tensile properties of microalloyed forging steels were studied. Four \\ kinds of microalloyed forging steels were produced by varying $W$ additions $(0,0.5,1$ and $2 \mathrm{wt} \%)$. Heat \\ treatment was carried out at temperatures ranging from 840 to $950^{\circ} \mathrm{C}$ followed by air and furnace \\ cooling. Mechanical tests were used to evaluate the room temperature Charpy impact and tensile \\ properties. The resulting microstructures were analysed via optical microscope (OM), scanning electron \\ microscope (SEM) and transmission electron microscope (TEM). The results show that the \\ microstructure and mechanical properties of the microalloyed forging steels are closely related to the $\mathrm{W}$ \\ content. Correct selection of heat treatment temperature and cooling method is very important to \\ enhance the mechanical properties. The optimum heat treatment temperatures obtained in this study are \\ $920,900,880$ and $860{ }^{\circ} \mathrm{C}$ for the steels with $0 \%, 0.5 \%, 1 \%$ and $2 \% \mathrm{~W}$, respectively. Both the impact \\ toughness and tensile properties of the microalloyed forging steels have been significantly enhanced \\ after heat treatment at the optimum temperatures followed by air cooling.
}

\section{Keywords}

microalloyed, forging, steels, addition, heat, treatment, conditions, microstructure, effects, mechanical, tungsten, properties

\section{Disciplines \\ Engineering | Science and Technology Studies}

\section{Publication Details}

Zhao, J., Jiang, Z. \& Lee, C. Soo. (2013). Effects of tungsten addition and heat treatment conditions on microstructure and mechanical properties of microalloyed forging steels. Materials Science and Engineering A: Structural Materials: Properties, Microstructure and Processing, 562 144-151. 


\title{
Effect of tungsten addition and heat treatment conditions on microstructure and mechanical properties of microalloyed forging steels
}

\author{
Jingwei Zhao ${ }^{1,2}$, Zhengyi Jiang², Chong Soo Lee ${ }^{1,3, *}$ \\ ${ }^{1}$ Department of Materials Science and Engineering, Pohang University of Science and Technology, Pohang \\ 790-784, Korea \\ ${ }^{2}$ School of Mechanical, Materials and Mechatronic Engineering, University of Wollongong, NSW 2522, \\ Australia \\ ${ }^{3}$ Graduate Institute of Ferrous Technology, Pohang University of Science and Technology, Pohang 790-784, \\ Korea
}

\begin{abstract}
In the present work, the effects of tungsten (W) addition and heat treatment conditions on the microstructure, impact toughness and tensile properties of microalloyed forging steels were studied. Four kinds of microalloyed forging steels were produced by varying $\mathrm{W}$ additions ( $0,0.5,1$ and $2 \mathrm{wt} . \%)$. Annealing treatment was carried out at temperatures ranging from 840 to $950^{\circ} \mathrm{C}$ followed by air and furnace cooling. Mechanical tests were used to evaluate the room temperature Charpy impact and tensile properties. The resulting microstructures were analysed via optical microscopy (OM), scanning electron microscopy (SEM) and transmission electron microscope (TEM). The results show that the addition of $\mathrm{W}$ plays an important role in increasing the strength and decreasing the toughness of the studied steels. Correct selection of annealing temperature and cooling method is very important to enhance the mechanical properties. The optimum annealing temperatures obtained in this study are $920,900,880$ and $860^{\circ} \mathrm{C}$ for the steels with $0,0.5,1$ and $2 \% \mathrm{~W}$, respectively. Both the impact toughness and tensile properties of the microalloyed forging steels have been significantly enhanced after heat treatment at the optimum temperatures followed by air cooling.
\end{abstract}

Keywords: Microalloyed forging steel; Tungsten; Heat treatment; Toughness; Tensile properties

\footnotetext{
* Corresponding author. Tel.: +82-54-279-2141; Fax: +82-54-279-2399.

E-mail addresses: jwzhaocn@gmail.com (J. Zhao), cslee@postech.ac.kr (C.S. Lee).
} 


\section{Introduction}

Many applications for structures, machine and vehicle parts require high strength and excellent toughness.

Traditionally, steels for these applications are produced by forging, and the required properties are obtained by quenching and tempering treatment. Interest has increased in the use of microalloyed forging steels in place of quenched-and-tempered steels to realise cost savings [1]. Microalloyed forging steels have been developed over the past several years and are increasingly applied in a variety of large-scale structures, engine, transmission, suspension and driveline components such as the flange, gears, springs, crankshafts, connecting rods, axles and shaft [2-6].

Microalloyed forging steels employ small amount of microalloying elements (niobium, vanadium or titanium) to improve microstructures and mechanical properties, or to enable alternative processing routes. The required strength level is mainly provided by grain refinement and/or precipitation strengthening from microalloying elements. Undissolved and precipitated carbides, nitrides or carbonitrides restrict the movement of either dislocations or interfaces and prevent grain coarsening during heating and processing, resulting in improved strength. Compared with conventional quenched-and-tempered steels, microalloyed forging steels exhibit not only simplified operation procedures, but also increased microstructure uniformity, less stress concentration and improved dimensional stability. Decreased toughness, however, is usually accompanied. The application of microalloyed forging steels has often been limited based on toughness consideration at the required strength level [7]. In an effort to acquire excellent toughness, appropriate heat treatment is usually performed on the microalloyed steels after forging [7-10].

The air-cooled microstructure of microalloyed forging steels is generally composed of ferrite and pearlite. The 
content, size and distribution of ferrite and pearlite within the microstructure play an important role in the final mechanical properties. As a strong ferrite former, tungsten (W) can restrain pearlite and ferrite transformations, and is effective for precipitate refining and solid solution strengthening. Several attempts have been made to improve the mechanical properties of steels through $\mathrm{W}$ alloying. The studied materials were mainly focused on stainless steels, oxide dispersion strengthened ferritic steels, maraging steels, and steels used in power-generation and chemical industries [11-16]. For microalloyed forging steels with different W contents, however, the mechanical properties have not been well reported. In particular, annealing heat treatment with purpose of achieving the best combination of required strength levels and acceptable toughness performed on W-containing microalloyed forging steels has been less investigated extensively.

In the present study, several microalloyed forging steels were produced by varying $\mathrm{W}$ additions. The aim of this investigation was to study the effects of $\mathrm{W}$ content, annealing temperature and cooling method on the microstructure, impact toughness and tensile properties of these microalloyed forging steels. Discussion was made on the mechanisms of improvement of mechanical properties after $\mathrm{W}$ addition and heat treatment.

\section{Experimental procedure}

Four kinds of steels with different $\mathrm{W}$ contents (0, 0.5, 1 and 2 wt.\%) were used in this study. The chemical composition of the steels is shown in Table 1 . Ingots were homogenised at $1230^{\circ} \mathrm{C}$ for $1 \mathrm{~h}$ and then hot forged to be a cube with cross section size of $140 \mathrm{~mm} \times 140 \mathrm{~mm}$ and height of $400 \mathrm{~mm}$ followed by air cooling. The final forging temperature was controlled to be higher than $950^{\circ} \mathrm{C}$. Specimens were prepared along the height direction of the forged pieces.

Preliminary investigation on the austenitisation start $\left(A_{\mathrm{c} 1}\right)$ and final $\left(A_{\mathrm{c} 3}\right)$ temperatures in heating was conducted 
via dilatometer tests prior to annealing heat treatment. The $A_{\mathrm{c} 1}$ and $A_{\mathrm{c} 3}$ temperatures of $0 \mathrm{~W}$ and $1 \mathrm{~W}$ specimens were determined as: $A_{\mathrm{c} 1}=766^{\circ} \mathrm{C}$ and $A_{\mathrm{c} 3}=903^{\circ} \mathrm{C}$ for $0 \mathrm{~W}$ specimen; $A_{\mathrm{c} 1}=771^{\circ} \mathrm{C}$ and $A_{\mathrm{c} 3}=910^{\circ} \mathrm{C}$ for $1 \mathrm{~W}$ specimen. In order to find the optimum heat treatment conditions, annealing at $840,860,880,900,920$ and $950^{\circ} \mathrm{C}$ for $1 \mathrm{~h}$ followed by air and furnace cooling were applied based on the determined $A_{\mathrm{c} 1}$ and $A_{\mathrm{c} 3}$ temperatures. Two groups of rectangular specimens with size of $11 \mathrm{~mm} \times 11 \mathrm{~mm} \times 60 \mathrm{~mm}$ and $11 \mathrm{~mm} \times 11 \mathrm{~mm} \times 110 \mathrm{~mm}$ respectively were cut from the forged steels. Annealing heat treatment was performed on these rectangular specimens using an electric furnace in laboratory.

Standard Charpy impact and tensile specimens were machined according to ASTM E 23 and ASTM E 8M, respectively. The Charpy V-notched specimens with cross section of $10 \mathrm{~mm} \times 10 \mathrm{~mm}$, length of $55 \mathrm{~mm}$, notch angle of $45^{\circ}$ and notch depth of $2 \mathrm{~mm}$ were employed to study the room temperature impact toughness on a Zwick/Roell impact tester. Tensile tests were performed using standard specimens (Gauge length $30 \mathrm{~mm}$, gauge diameter $6 \mathrm{~mm}$ ) on an Instron 8801 tensile testing machine at room temperature with strain rate of $5 \times 10^{-3} \mathrm{~s}^{-1}$. The resulting stress-strain curves were analysed to determine the yield strength (YS, $0.2 \%$ proof stress) and ultimate tensile strength (UTS).

Optical microscopy (OM), scanning electron microscopy (SEM) and transmission electron microscope (TEM) were used to identify microstructure. For OM observation, specimens were metallographically polished and then etched with $2 \%$ nital solution. Slightly overetched specimens were examined under SEM. To examine the characteristic of precipitates, extraction replicas as well as thin foils mounted on $\mathrm{Cu}$ grids specimens were prepared and analysed on TEM operated at $200 \mathrm{kV}$. Fracture surfaces of the tested specimens were examined on SEM using an accelerating voltage of $15 \mathrm{kV}$ to determine the failure mode. 


\section{Results}

\subsection{Mechanical properties}

\subsubsection{Charpy impact properties}

Fig. 1a and $\mathrm{b}$ shows the dependence of impact energies on heat treatment temperatures under air and furnace cooling conditions, respectively. For comparison, the impact energies of the as-forged specimens are also presented in Fig. 1. It can be seen that the toughness levels of the as-forged specimens are very low, and the addition of $\mathrm{W}$ results in decreased impact energies. The toughness of the as-forged specimens has been significantly enhanced after heat treatment. The impact energy of the heat-treated $0 \mathrm{~W}$ specimen suffered from air cooling exhibits higher value than that suffered from furnace cooling, while the heat-treated W-containing specimens subjected to furnace cooling show higher toughness level than that subjected to air cooling. The highest impact energies of the heat-treated 0, 0.5, 1 and 2W specimens suffered from air cooling are 208.3, 66.0, 51.9 and $23.4 \mathrm{~J}$, and the corresponding annealing temperatures are $920,900,880$ and $860^{\circ} \mathrm{C}$, respectively. Differently, all the furnace-cooled specimens exhibit their highest toughness levels at $880^{\circ} \mathrm{C}$, and the maximum impact energies of the heat-treated 0, 0.5, 1 and 2W specimens are 149.6, 120.3, 82.2 and $47.2 \mathrm{~J}$, respectively.

\subsubsection{Tensile properties}

Table 2 illustrates the tensile properties of the as-forged specimens. It can be seen that the addition of W brings about increase in both YS and UTS at the expense of strain.

The heat-treated specimens with the highest toughness levels under both air and furnace cooling conditions were employed to do the tensile tests. The typical tensile curves are presented in Fig. 2. The tensile properties determined from these curves are listed in Table 3. The result shown in Fig. 2a indicates that the addition of W 
leads to continuous yielding when the heat-treated specimens suffered from air cooling. Under furnace cooling condition, the tensile behaviour of $2 \mathrm{~W}$ specimen with continuous yielding is different from that of other three specimens in which apparent yield points can be observed, as shown in Fig. 2b. Based on Table 3, the heat-treated specimens subjected to air cooling exhibit higher strength levels than that subjected to furnace cooling at the expense of strain. According to Tables 2 and 3, it is apparent that both the tensile strength and strain of the as-forged specimens have been significantly increased after heat treatment followed by air cooling. Under furnace cooling condition, however, the decreased tensile strength of the as-forged specimens is caused, even though the strain has been greatly increased.

\subsection{Microstructure}

The microstructures of the as-forged specimens are shown in Fig. 3, presenting a great difference in the structure morphology at different $\mathrm{W}$ content levels. The specimen without $\mathrm{W}$ consists mainly of polygonal ferrite (PF) and pearlite, as shown in Fig. 3a. The addition of W has changed the microstructures significantly. Allotriomorphic ferrite forms in the 0.5W specimen, companied with large quantity of acicular ferrite (AF), as shown in Fig. 3b. Allotriomorphic ferrite is the first phase to form on cooling the austenite grains below the $\mathrm{Ae}_{3}$ temperature [17]. It nucleates at the columnar austenite grain boundaries. Because these boundaries are easy diffusion paths, they become decorated with continuous layers of ferrite. With continuous increasing W from 0.5 to $1 \%$, allotriomorphic ferrite disappears, and the microstructure becomes a mixture of AF and small amount of bainite (Fig. 3c). When the $\mathrm{W}$ content is increased to $2 \%$, the microstructure, which is dominated by bainite, is still composed of AF and bainite, as shown in Fig. 3d.

The microstructures of the air-cooled specimens according to Table 3 are presented in Fig. 4 . As can be seen, the microstructure of the air-cooled 0W specimen consists of equiaxed ferrite and pearlite, and the grain size 
distribution is very uniform (Fig. 4a). According to Figs. 3a and 4a, it is apparent that annealing heat treatment has significantly refined the microstructure of the as-forged $0 \mathrm{~W}$ specimen. In contrast to that in $0 \mathrm{~W}$ specimen, small amount of bainite appears in the microstructure of $0.5 \mathrm{~W}$ specimen (Fig. 4b). With increasing W content, the amount of bainite increases, as shown in Figs. 4c and d. In addition, the size of bainite packets has been greatly refined after annealing heat treatment.

Fig. 5 illustrates the microstructures of the furnace-cooled 1 and $2 \mathrm{~W}$ specimens according to Table 3 . It can be seen from Fig. 5a that the microstructure of the furnace-cooled $1 \mathrm{~W}$ specimen is mixed by equiaxed ferrite and pearlite. Differently, small amount of bainite appears in the microstructure when the $\mathrm{W}$ content is increased to 2\%, as shown in Fig. 5b. Moreover, furnace cooling induces coarser grains compared to that under air cooling condition at the same annealing temperature, as presented in Figs. 4c and 5a.

\subsection{Fractography}

Selected fracture surfaces in the shear lip areas of some impact specimens are demonstrated in Fig. 6. It can be seen from Fig. 6a that the as-forged 0W specimen exhibits a brittle cleavage fracture. The fracture surface of the heat-treated 0W specimen suffered from air cooling is composed of small, deep and uniformly distributed dimples, which indicates the ductile nature of fracture, as shown in Fig. 6b. Based on Fig. 6b and c, furnace cooling leads to larger dimples compared to that suffered from air cooling. The fracture surface of the as-forged $0.5 \mathrm{~W}$ specimen is a mixture of large cleavage facets and shear cracks, which also shows a characteristic of brittle fracture, as shown in Fig. 5d. After annealing heat treatment followed by air cooling, the fracture surface of $0.5 \mathrm{~W}$ specimen becomes a mixture of cleavage facets and small dimples, as shown in Fig. 6e. However, as shown in Fig. 6f, a ductile mode fracture is obtained when the heat-treated $0.5 \mathrm{~W}$ specimen suffered from furnace cooling. 
Fig. 7 shows the tensile fracture morphologies of $0,0.5$ and $2 \mathrm{~W}$ specimens. It can be seen that all the fracture surfaces are composed of dimples, which indicate a characteristic of ductile fracture. The size of dimples exhibits a decrease trend with the increase of W content (Fig. 7a - c). Moreover, as shown in Fig. 7d - f, annealing heat treatment has a beneficial effect on reducing the size of dimples.

\section{Analysis and discussion}

\subsection{Variation of mechanical properties after $W$ addition}

When the $\mathrm{W}$ content is increased from 0 to $0.5 \%$, the microstructure becomes a mixture of allotriomorphic ferrite and AF instead of PF and pearlite. The shape change is always associated with the growth of AF, and such shape change causes plastic deformation in the adjacent austenite. As reported by Strangwood [18], the resulting dislocations are inherited by the $\mathrm{AF}$ as it grows, giving a dislocation density which is typically at $10^{14}$ $\mathrm{m}^{-2}$, and which contribute some $145 \mathrm{MPa}$ to its strength. When the $\mathrm{W}$ content is increased to $1 \%$, the allotriomorphic ferrite disappears, and the microstructure is mixed by AF and small amount of bainite. The measured dislocation density of bainite $\rho_{d}$ was to be about $4 \times 10^{14} \mathrm{~m}^{-2}$ [19], which is higher than that of allotriomorphic ferrite obtained in the same steel with $\rho_{d} \approx 0.5 \times 10^{14} \mathrm{~m}^{-2}$. In another supporting experiment, similar results of the dislocation densities of bainite and allotriomorphic ferrite were measured to be $1.7 \times 10^{14}$ and $0.37 \times 10^{14} \mathrm{~m}^{-2}$, respectively [20]. It then follows that bainite contains more dislocations than allotriomorphic ferrite and hence improve the tensile strength. When the $\mathrm{W}$ content is increased to $2 \%$, the microstructure is dominated by bainite, and will cause further increased tensile strength.

As to the reasons of strength increasing after $\mathrm{W}$ addition, the following other causes are considered. One is the solid solution strengthening induced by $\mathrm{W}$ addition, which results from the fact that the atomic size of $\mathrm{W}$ is about $10 \%$ larger than that of Fe. The other is the hardening induced by the fine precipitates in $\mathrm{W}$-containing 
steels. With refinement of various precipitates, the barriers of the dislocation motion increase with the increase of interphase boundaries, leading to an increase in the strength in this way. Fig. 8a and b presents the characteristic of precipitates in the as-forged 0 and $2 \mathrm{~W}$ specimens, respectively. It is apparent that the precipitates have been significantly refined after $\mathrm{W}$ addition, and hence increased tensile strength is expected.

\subsection{Effect of heat treatment on mechanical properties}

As is well known, the yield strength of a polycrystalline solid increases in a linear manner with $d^{-1 / 2}$ ( $d$ is the grain size), and ductile to brittle transition temperature decreases in proportion to $d^{-1 / 2}$ [21]. Thus, grain refinement increases both strength and toughness. After heat treatment followed by air cooling, both the strength and toughness of the as-forged 0W specimen are significantly enhanced. According to Figs. 3a and 4a, these enhanced strength and toughness levels are closely related to the remarkable ferrite grain refinement. Since the $A_{\mathrm{c} 3}$ temperature of $0 \mathrm{~W}$ specimen is $903^{\circ} \mathrm{C}$, annealing heat treatment at temperatures lower than $903^{\circ} \mathrm{C}$ induces incomplete austenitisation, leading to non-uniform distribution of ferrite. Coarser ferrite grains will be caused if the austenitising temperature is higher than $920^{\circ} \mathrm{C}$ due to the increase of austenite grain size with temperature. These will consequently reduce the toughness. Under furnace cooling condition, the reduction in impact energy for $0 \mathrm{~W}$ specimen should be attributed to the coarsening of ferrite grains during the very slow cooling process.

The hardenability increases after $\mathrm{W}$ addition, promoting the formation of bainite [22]. Since bainite does not facilitate the enhancement of toughness but strength compared with ferrite, the formation of bainite under air cooling condition is responsible for the lower toughness and higher strength than that suffered from furnace cooling. In contrast to the optimum temperatures corresponding to the highest toughness values under air cooling condition, higher temperature induces larger bainite packet, and lower temperature leads to the 
formation of non-uniformly distributed microstructure, as shown in Fig. 9. During cleavage failure, the cracks propagate undeviated across individual packets of bainite [23], and the size of cleavage facets obtained by brittle fracture correlates well with the size of the bainite [24]. These microstructural morphologies formed at either higher or lower temperature is, therefore, unfavourable to enhance the toughness. Therefore, there is an optimum temperature for obtaining the excellent mechanical properties, and the microstructural characteristic plays important roles in the enhancement of both impact toughness and tensile strength.

Tensile curves for the air-cooled $0 \mathrm{~W}$ and the furnace-cooled $0,0.5$ and $1 \mathrm{~W}$ specimens after heat treatment exhibit discontinuous yielding behaviour. According to the results of microstructural observation, all these specimens present the same microstructural characteristic mixed by ferrite and pearlite. Differently, bainite exists in all the microstructures of other specimens who have continuous yielding behaviour. The factors which govern discontinuous yielding in steels are [25-27]: (I) low mobile dislocation density of the order of $10^{2} \sim 10^{4}$ $\mathrm{cm}^{-2}$ prior to deformation, (II) a rapid rise in the number of dislocations that occur during deformation and (III) a strong dependence of the dislocation rate on the applied stress. To achieve discontinuous yielding, pinning of dislocations during deformation is essential. Cottrell [28] established the basis of the pinning of dislocations by interstitial atoms in ferrite. According to this theory, the pinning of dislocations by segregated interstitial atoms in ferrite is so strong effectively that all dislocations are immobilised. For plastic deformation to proceed, new dislocations must be generated, provided a sufficient stress is applied. As a result, discontinuous yielding in the ferrite-pearlite specimens will appear. In the bainite-containing specimens, the majority of dislocations produced during bainite transformation are mobile in nature [29], even though a considerable number of dislocations can be generated by the transformation of austenite to bainite. Therefore, the observed continuous yielding behavior of the bainite-containing specimens is attributed to the possibility that a high density of mobile dislocations is produced due to the formation of bainite in the microstructures. 


\section{Conclusions}

1. The mechanical properties of the microalloyed forging steels are related closely to the $\mathrm{W}$ content. The addition of W results in increased strength and decreased toughness.

2. The toughness of the heat-treated $0 \mathrm{~W}$ steel suffered from air cooling is better than that suffered from furnace cooling, while the heat-treated W-containing steels subjected to furnace cooling show higher toughness levels than that subjected to air cooling.

3. Correct selection of annealing temperature and cooling method is very important to obtain the best combination of excellent impact toughness and tensile properties. The optimum annealing temperatures obtained in this study are $920,900,880$ and $860^{\circ} \mathrm{C}$ for $0,0.5,1$ and $2 \mathrm{~W}$ steels, respectively.

4. Both the impact toughness and tensile properties of the microalloyed forging steels can be significantly enhanced after annealing heat treatment at the optimum temperatures followed by air cooling. 


\section{References}

[1] L. Yang, A. Fatemi, J. Eng. Mater. Technol. 118 (1996) 71-79.

[2] Y.J. Zhang, W.J. Hui, D. Han, J. Iron Steel Res. Int. 14 (2007) 189-194.

[3] A.B. Cota, F.L.G. Oliveira, A.L.R. Barbosa, C.A.M. Lacerda, F.G.S. Araujo, Mater. Res. 6 (2003) $117-121$

[4] K.A. Bello, S.B. Hassan, M. Abdulwahab, J. Appl. Sci. Res. 3 (2007) 1719-1723.

[5] D.K. Matlock, J.G. Speer, Mater. Sci. Technol. 25 (2009) 1118-1125.

[6] J. Mougin, P. Dieric Simsir kx, D. Robat, J. Rofes Vernis, Mater. Sci. Forum 500-501 (2005) 753-760.

[7] T.J. Liu, Modeling microstructural evolution of microalloyed forging steels during thermomechanical processing, Ph.D. Thesis, Queen’s University, Kingston, 2001, p. 1.

[8] D.K. Matlock, G. Krauss, J.G. Speer, J. Mater. Process. Technol. 117 (2001) 324-328.

[9] D.J. Naylor, Mater. Sci. Forum 284-286 (1998) 83-94.

[10] I. Gonzalez-Baquet, R. Kaspar, J. Richter, G. Nußbaum, A. Kothe, Mater. Sci. Forum 284-286 (1998) 411-418.

[11] S.B. Kim, K.W. Paik, Y.G. Kim, Mater. Sci. Eng. A 247 (1998) 67-74.

[12] J.I. Suk, C.N. Park, S.H. Hong, Y.G. Kim, Mater. Sci. Eng. A 138 (1991) 367-273.

[13] T. Narita, S. Ukai, S. Ohtsuka, M. Inoue, J. Nucl. Mater. 417 (2011) 158-161.

[14] S.G. Hong, W.B. Lee, C.G. Park, Scr. Mater. 43 (2000) 181-186.

[15] W.J. Nam, C.S. Lee, D.Y. Ban, Scr. Mater. 36 (1997) 1315-1320.

[16] J.S. Park, S.J. Kim, C.S. Lee, Mater. Sci. Eng. A 298 (2001) 127-136.

[17] H.K.D.H. Bhadeshia, R.W.K. Honeycombe, Steels: microstructure and properties, 3rd ed., Elsevier Butterworth-Heinemann, Oxford, 2006, p. 291. 
[18] M. Strangwood, H.K.D.H. Bhadeshia, Advances in welding science and technology (ed. S.A. David), ASM, Metals Park, Ohio, 1987, pp. 209-213.

[19] H.K.D.H. Bhadeshia, Bainite in steels, 2nd ed., The University Press, Cambridge, London, 2001, p. 26.

[20] M.K. Graf, H.G. Hillenbrand, P.A. Peters, Accelerated Cooling of Steel (ed. P.D. Southwick), TMS-AIME, 1985, pp. 349-366.

[21] M. Srinivas, G. Malakondaiah, R.W. Armstrong, P. Rama Rao, Acta Metall. Mater. 39 (1991) 807-816.

[22] R.L. Klueh, D.J. Alexander, P.J. Maziasz, Metall. Mater. Trans. A 28 (1997) 335-346.

[23] F.B. Pickering, Transformation and hardenability in steels, Climax Molybdenum Co., Ann Arbor, Michigan, 1967, pp. 109-132.

[24] J.P. Naylor, P.R. Krahe, Metall. Trans. 5 (1974) 1699-1701.

[25] J.M. Rigsbee, J.K. Abrahm, A.T. Davenport, J.E. Franklin, J.W. Pickens, [in:] Structure and Properties of Dual phase Steels, R.A. Kot, J.W. Morris (Eds.), AIME, New York, 1979, pp. 304-329.

[26] R.G. Davis, C.L. Magee, Dual Phase and Cold Pressing Vanadium Steels in the Automobile Industry, Vanitec, Berlin, 1978, p. 25.

[27] S.R. Mediratta, V. Ramaswamy, V. Singh, P. Rama Rao, Trans. Indian Inst. Met. 38 (1985) 350-372.

[28] A.H. Cottrell, Dislocations and Plastic Flow in Crystals, Oxford University Press, Oxford, England, 1953, p.134.

[29] A. Barbacki, J. Mater. Process.Technol. 53 (1995) 57-63. 


\section{Figure Captions:}

Fig. 1. Dependence of impact energies on temperatures under (a) air and (b) furnace cooling conditions.

Fig. 2. Typical tensile curves of the specimens after annealing heat treatment followed by (a) air and (b) furnace cooling.

Fig. 3. OM (a,b) and SEM (c,d) structures of the as-forged specimens: (a) 0W, (b) 0.5W, (c) $1 \mathrm{w}$, and (d) $2 \mathrm{~W}$.

Fig. 4. Microstructures of the air-cooled specimens according to Table 4 : (a) $0 \mathrm{~W}+920^{\circ} \mathrm{C}$, (b) $0.5 \mathrm{~W}+900^{\circ} \mathrm{C}$,

(c) $1 \mathrm{~W}+880^{\circ} \mathrm{C}$, and (d) $2 \mathrm{~W}+860^{\circ} \mathrm{C}$.

Fig. 5. Microstructures of the furnace-cooled specimens according to Table 4 : (a) $1 \mathrm{~W}+880^{\circ} \mathrm{C}$, and (b) $2 \mathrm{~W}+880^{\circ} \mathrm{C}$.

Fig. 6. Selected fracture surfaces in the shear lip areas of (a,b,c) 0 and (d,e,f) $0.5 \mathrm{~W}$ specimens after Charpy impact tests: (a,d) as-forged, (b) $920^{\circ} \mathrm{C}+$ air cooling, (c,f) $880^{\circ} \mathrm{C}+$ furnace cooling, and (e) $900^{\circ} \mathrm{C}+$ air cooling.

Fig. 7. Tensile fracture morphologies of (a,d) 0 , (b,e) 0.5 and (c,f) $2 \mathrm{~W}$ specimens: (a,b,c) as-forged, (d) $920^{\circ} \mathrm{C}+$ air cooling, (e) $900^{\circ} \mathrm{C}+$ air cooling, and (f) $860^{\circ} \mathrm{C}+$ air cooling.

Fig. 8. Characteristic of precipitates in the as-forged (a) 0 and (b) $2 \mathrm{~W}$ specimens.

Fig. 9. Microstructures of the heat-treated $1 \mathrm{~W}$ specimen after air cooling: (a) $840^{\circ} \mathrm{C}$, and (b) $950^{\circ} \mathrm{C}$. 
Table Captions:

Table 1 Chemical composition of the investigated steels (wt.\%).

Table 2 Tensile properties of the as-forged specimens.

Table 3 Tensile properties of the specimens after annealing heat treatment. 

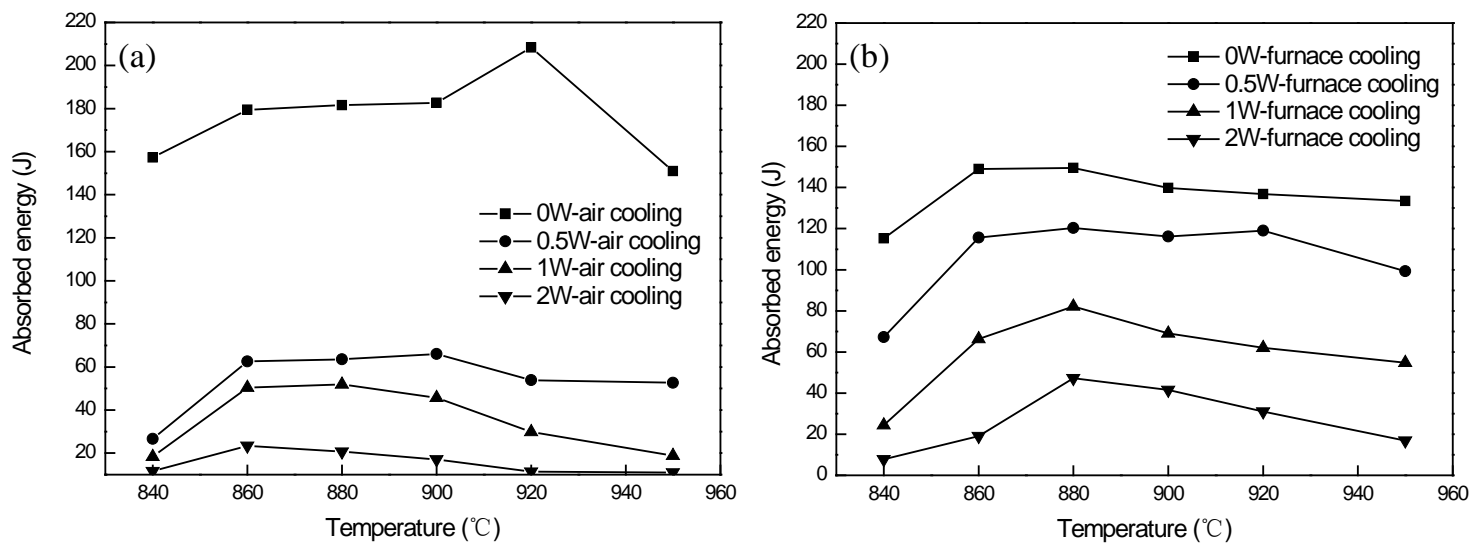

Note: the impact energies of the as-forged specimens are 19.3, 14.5, 10.6 and 9.8 J for 0, 0.5, 1 and 2W, respectively.

Fig. 1. Dependence of impact energies on temperatures under (a) air and (b) furnace cooling conditions.
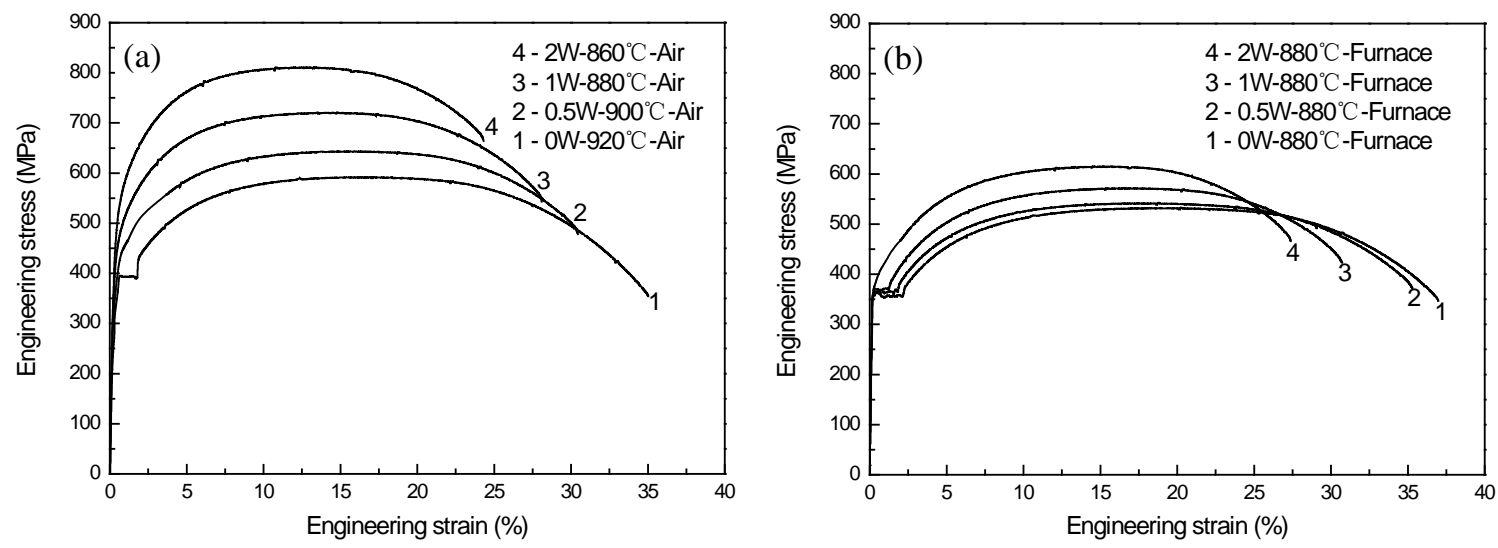

Fig. 2. Typical tensile curves of the specimens after heat treatment followed by (a) air and (b) furnace cooling. 

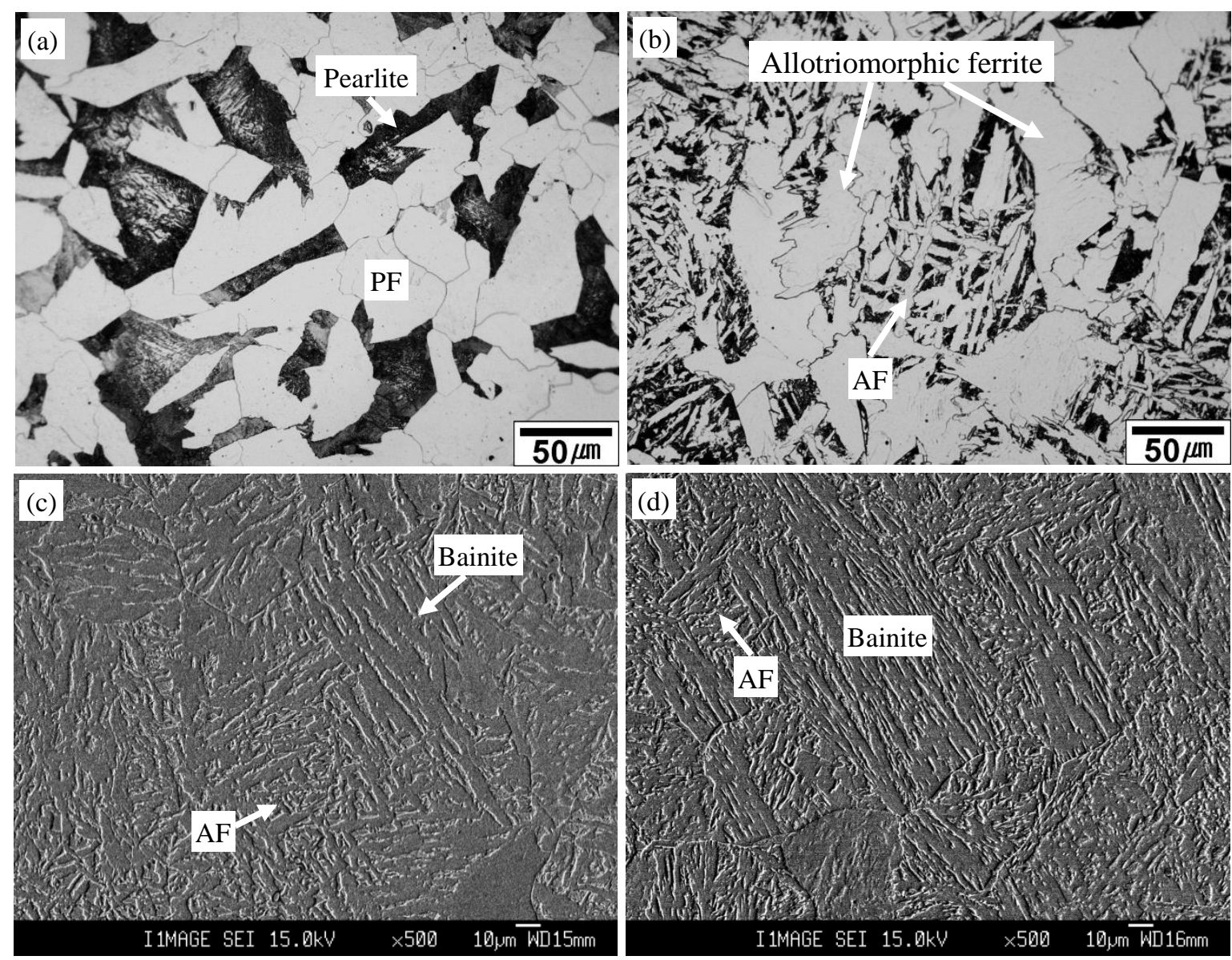

Fig. 3. OM (a,b) and SEM (c,d) structures of the as-forged specimens. (a) $0 \mathrm{~W}$, (b) $0.5 \mathrm{~W}$, (c) $1 \mathrm{w}$ and (d) $2 \mathrm{~W}$. 


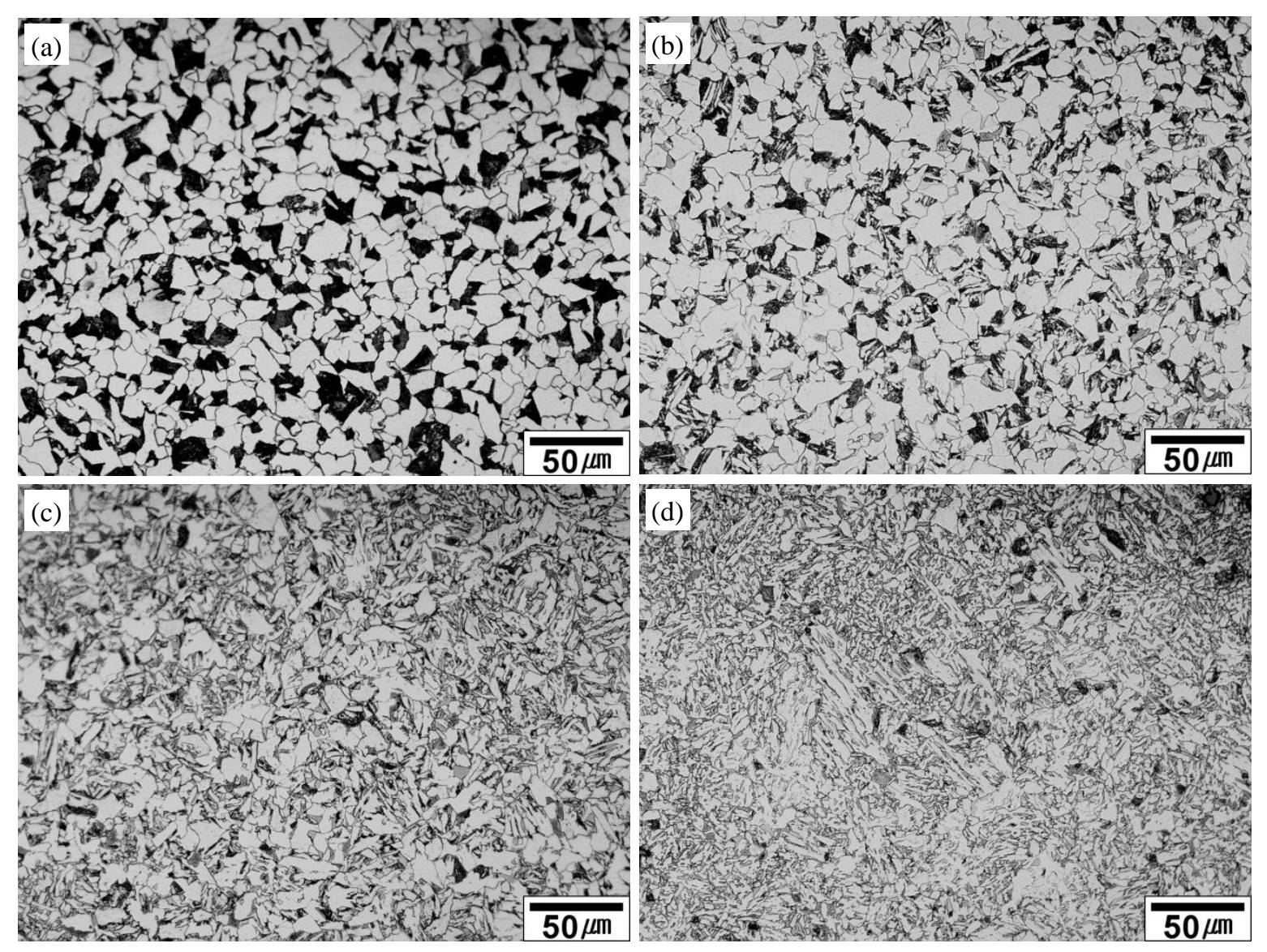

Fig. 4. Microstructures of the air-cooled specimens according to Table 4. (a) $0 \mathrm{~W}+920^{\circ} \mathrm{C}$, (b) $0.5 \mathrm{~W}+900^{\circ} \mathrm{C}$, (c) $1 \mathrm{~W}+880^{\circ} \mathrm{C}$ and (d) $2 \mathrm{~W}+860^{\circ} \mathrm{C}$.
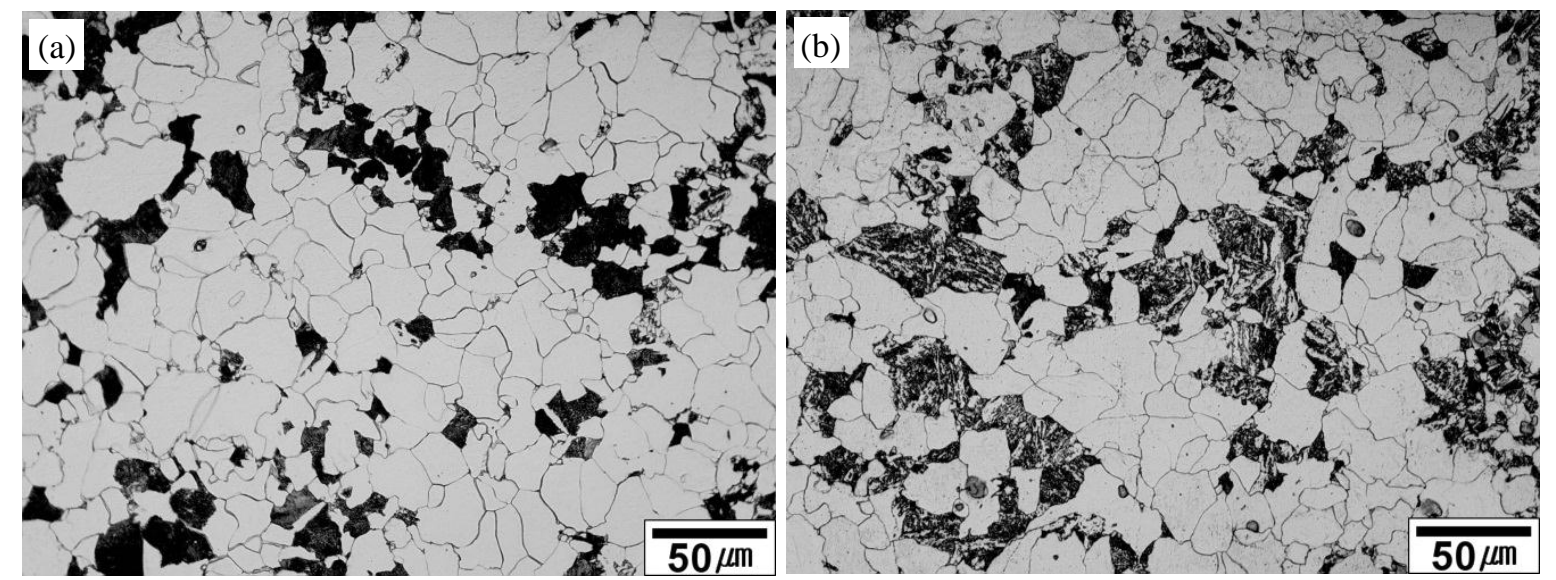

Fig. 5. Microstructures of the furnace-cooled specimens according to Table 4 . (a) $1 \mathrm{~W}+880^{\circ} \mathrm{C}$ and (b) $2 \mathrm{~W}+880^{\circ} \mathrm{C}$. 

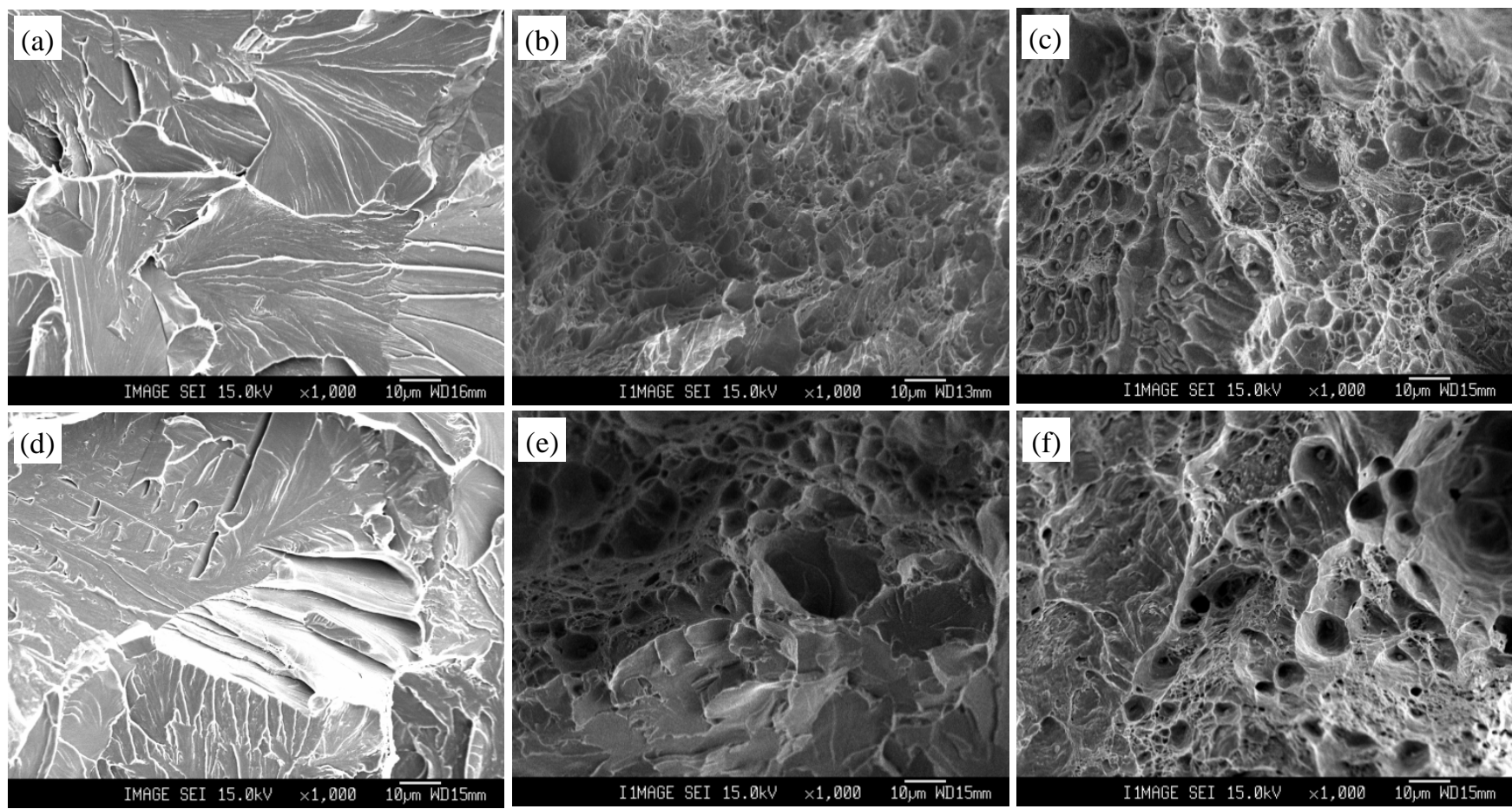

Fig. 6. Selected fracture surfaces in the shear lip areas of (a,b,c) 0 and (d,e,f) $0.5 \mathrm{~W}$ specimens after Charpy impact tests. (a,d) as-forged, (b) $920^{\circ} \mathrm{C}+$ air cooling, (c,f) $880^{\circ} \mathrm{C}+$ furnace cooling and (e) $900^{\circ} \mathrm{C}+$ air cooling.
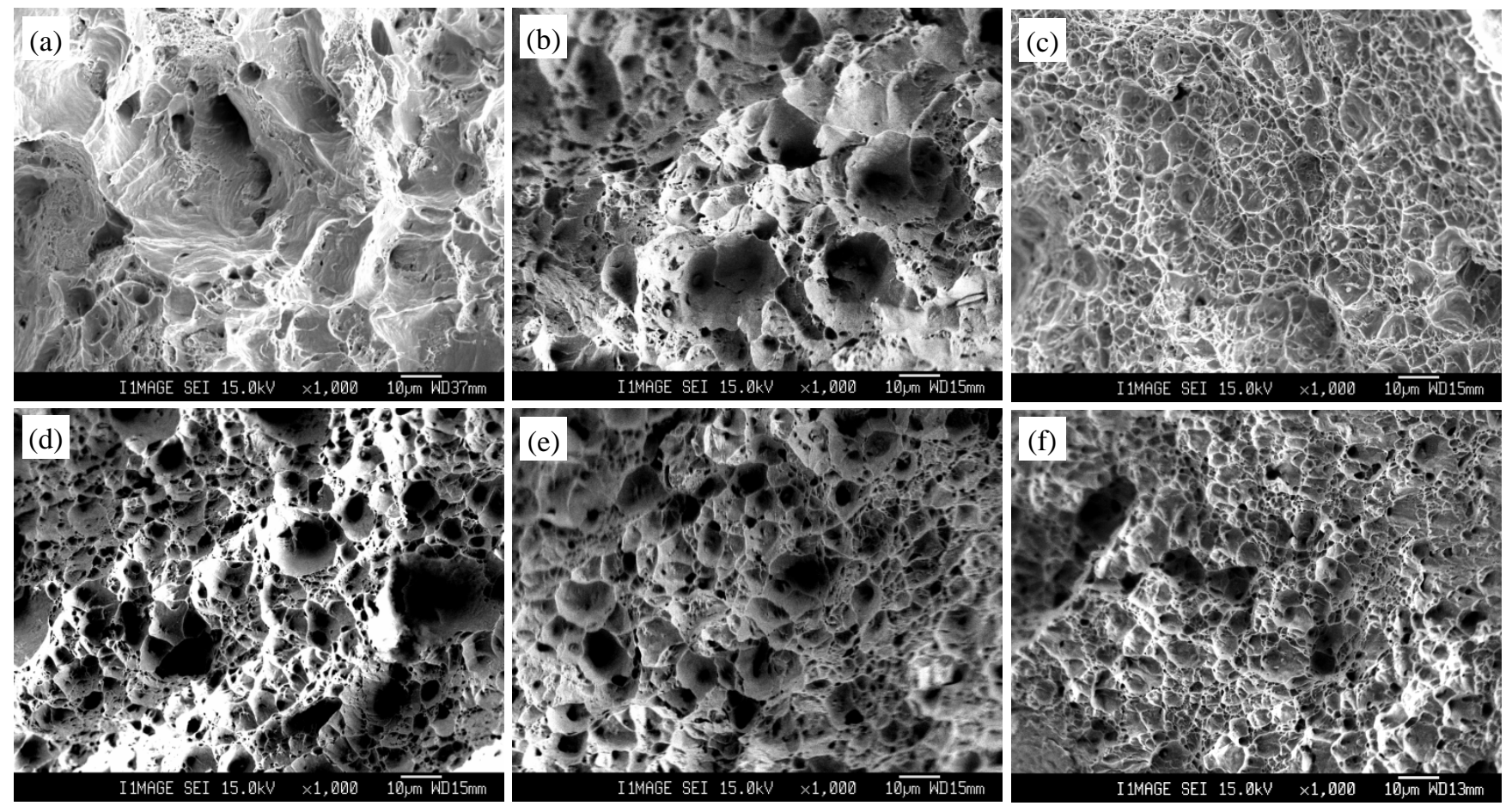

Fig. 7. Tensile fracture morphologies of (a,d) 0, (b,e) 0.5 and (c,f) $2 \mathrm{~W}$ specimens. (a,b,c) as-forged, (d) $920^{\circ} \mathrm{C}+$ air cooling, (e) $900^{\circ} \mathrm{C}+$ air cooling and (f) $860^{\circ} \mathrm{C}+$ air cooling. 

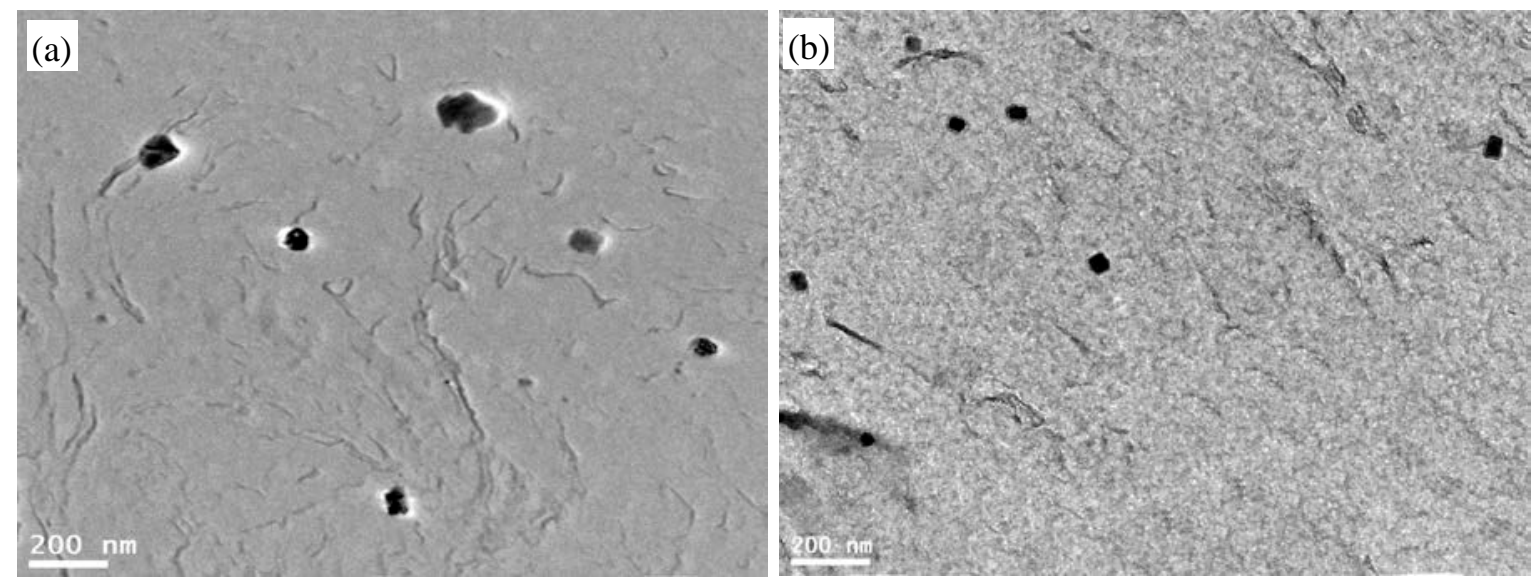

Fig. 8. Characteristic of precipitates in the as-forged (a) 0 and (b) $2 \mathrm{~W}$ specimens.
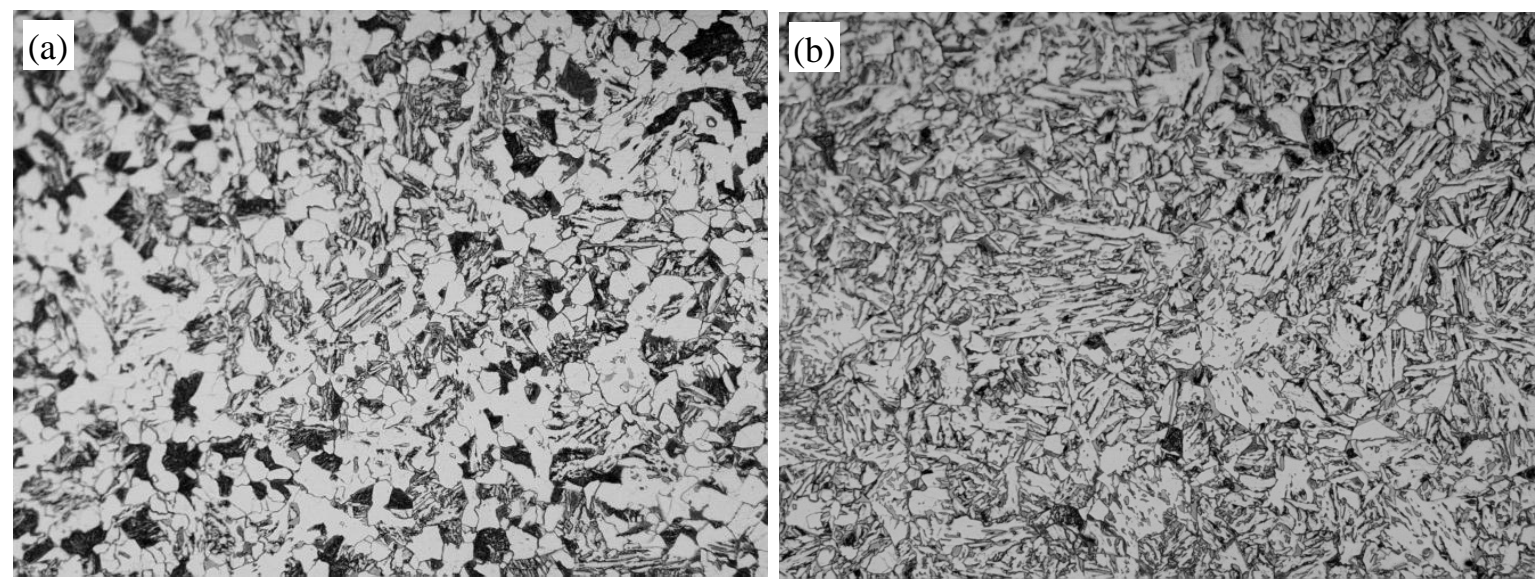

Fig. 9. Microstructures of the heat-treated $1 \mathrm{~W}$ steel after air cooling. (a) $840^{\circ} \mathrm{C}$ and (b) $950^{\circ} \mathrm{C}$. 
Table 1 Chemical composition of the investigated steels (wt.\%).

\begin{tabular}{ccccccccccccccc}
\hline Specimens & $\mathrm{C}$ & $\mathrm{Mn}$ & $\mathrm{Cr}$ & $\mathrm{Ni}$ & $\mathrm{Cu}$ & $\mathrm{Si}$ & $\mathrm{Al}$ & $\mathrm{V}$ & $\mathrm{Nb}$ & $\mathrm{Ti}$ & $\mathrm{P}$ & $\mathrm{S}$ & $\mathrm{N}$ & $\mathrm{W}$ \\
\hline 0W & 0.17 & 1.2 & 0.1 & 0.02 & 0.02 & 0.47 & 0.02 & 0.01 & 0.02 & 0.02 & 0.01 & 0.01 & 0.006 & 0 \\
$0.5 \mathrm{~W}$ & 0.17 & 1.2 & 0.1 & 0.02 & 0.02 & 0.47 & 0.02 & 0.01 & 0.02 & 0.02 & 0.01 & 0.01 & 0.006 & 0.5 \\
$\mathrm{1W}$ & 0.17 & 1.2 & 0.1 & 0.02 & 0.02 & 0.47 & 0.02 & 0.01 & 0.02 & 0.02 & 0.01 & 0.01 & 0.006 & 1.0 \\
$\mathrm{2W}$ & 0.17 & 1.2 & 0.1 & 0.02 & 0.02 & 0.47 & 0.02 & 0.01 & 0.02 & 0.02 & 0.01 & 0.01 & 0.006 & 2.0 \\
\hline
\end{tabular}

Table 2 Tensile properties of the as-forged specimens.

\begin{tabular}{llll}
\hline Specimen & YS (MPa) & UTS (MPa) & Strain (\%) \\
\hline 0W & 363.2 & 592.7 & 29.4 \\
$0.5 \mathrm{~W}$ & 382.7 & 645.0 & 22.9 \\
WW & 400.5 & 706.1 & 21.9 \\
2W & 414.3 & 751.7 & 20.8 \\
\hline
\end{tabular}

Table 3 Tensile properties of the specimens after heat treatment.

\begin{tabular}{|c|c|c|c|c|c|}
\hline Specimen & Annealing temperature $\left({ }^{\circ} \mathrm{C}\right)$ & Cooling method & YS (MPa) & UTS (MPa) & Strain (\%) \\
\hline oW & 920 & Air & 390.1 & 593.2 & 35.0 \\
\hline $0.5 \mathrm{~W}$ & 900 & Air & 431.1 & 655.7 & 30.5 \\
\hline $1 \mathrm{~W}$ & 880 & Air & 476.9 & 724.7 & 28.1 \\
\hline $2 \mathrm{~W}$ & 860 & Air & 532.6 & 811.6 & 24.3 \\
\hline oW & 880 & Furnace & 356.3 & 533.1 & 37.0 \\
\hline $0.5 \mathrm{~W}$ & 880 & Furnace & 364.7 & 542.6 & 35.3 \\
\hline $1 \mathrm{~W}$ & 880 & Furnace & 382.2 & 572.7 & 30.7 \\
\hline $2 \mathrm{~W}$ & 880 & Furnace & 409.5 & 615.5 & 27.4 \\
\hline
\end{tabular}

